\title{
The Gesneriaceae of India: Consequences of updated generic concepts and new family classification
}

\author{
Michael Möller*1, Santhosh Nampy², A.P. Janeesha² and Anton Weber ${ }^{3}$ \\ ${ }^{1}$ Royal Botanic Garden Edinburgh, Edinburgh EH3 5LR, Scotland, UK. \\ 2University of Calicut, Thenhipalam P.O., Malappuram District, Kerala - 673635, India. \\ ${ }^{3}$ Department of Botany and Biodiversity Research, Faculty Centre Biodiversity, University of Vienna, \\ 1030 Vienna, Austria. \\ *E-mail: m.moeller@rbge.ac.uk
}

\begin{abstract}
For the Gesneriaceae of India the consequences of revised generic circumscriptions and the new classification based on molecular phylogenetic work are summarised and outlined. An identification key, genus descriptions and some considerations on the biogeographic distribution of the genera in India are provided. The current genus count in India is 23, with Briggsia Craib having disappeared and Cyrtandromoea Zoll. being excluded from Gesneriaceae. The Indian species formerly included in Boea Comm. ex Lam. and Paraboea (C.B. Clarke) Ridl. are now included in Dorcoceras Bunge and Middletonia C. Puglisi, respectively. Oreocharis Benth. is newly recorded for India due to the transfer of Briggsia muscicola (Diels) Craib to Oreocharis. The Indian genera are from both tribes of subfamily Didymocarpoideae, namely Epithemateae and Trichosporeae. The genera are represented in three out of four subtribes of tribe Epithemateae and six out of ten subtribes in tribe Trichosporeae, thus, in total the Indian genera are represented in nine out of fourteen subtribes in the subfamily Didymocarpoideae. Subtribe Jerdoniinae is endemic to India. This high level of diversity underlines the biogeographical and historical importance of India for the family Gesneriaceae.
\end{abstract}

Keywords: Dorcoceras, Gesneriaceae, India, Jerdoniinae, Middletonia, Oreocharis

\section{Introduction}

The present paper provides an overview of the Gesneriaceae Rich. \& Juss. in India with emphasis on the new generic delineations, and the placement of the genera in the new classification for the family. Consequences of these changes include the disappearance of some generic names and the appearance of new ones. An account of the Gesneriaceae occurring in Northeast India was published recently, though it was not based on the latest classification or the revised genus boundaries (Sinha \& Datta, 2016). In the following an account of the current status of the genera in India is provided.

Gesneriaceae are a medium-sized plant family of the order Lamiales (e.g. Schäferhoff et al., 2010). The family comprises around 3400 species and has roughly a third of its distribution in the Neotropics and two-thirds in the Paleotropics, with some outliers in Europe and the southern hemisphere (Weber et al., 2013). Recent molecular-phylogenetic work laid the basis for a new classification of the family (Möller \& Clark 2013; Weber et al., 2013). In this classification three major changes to the last formal classification of Burtt \& Wiehler (1995) were made: (1) Sanango G.S. Bunting \& Duke is added as a monotypic subfamily (subfam. Sanangoideae A. Weber, J.L. Clark \& Mich. Möller), (2) subfam. Gesnerioideae Burnett ('New World Gesneriaceae') now also includes the southern hemispherical Coronantheroideae Wiehler and the Old World tribe Titanotricheae T. Yamaz. ex W.T. Wang, and the former tribes Gloxinieae Fritsch and Episcieae Endl. are now combined in tribe Gesnerieae Dumort. This subfamily now has 5 tribes and 12 subtribes; and (3) subfam. Didymocarpoideae Arn. (synonym: Cyrtandroideae Burnett) includes the tribes Epithemateae C.B. Clarke (synonym: Klugieae Fritsch) and Trichosporeae Nees ("Epithematoid" and "Didymocarpoid Gesneriaceae" sensu Weber, 2004) which also contains members of the former tribes Cyrtandreae G. Don and Didymocarpeae Endl. The two tribes are divided into 14 subtribes (Fig. 1).

\section{Past and recent taxonomic changes}

With focus on the present political boundary of India, Clarke (1884) in Hooker's Flora of British India 




Fig. 1. Genera of Gesneriaceae of India in the new classification of Weber et al. (2013), with approximate number of species in India and in total given in brackets.

listed 20 genera. Since then, the circumscription of several genera changed and some were merged into others, while a few represent segregates from existing ones or were resurrected. A few genera were added subsequently from later collections (Beccarinda Kuntze, Hemiboea C.B. Clarke, Oreocharis Benth., Petrocosmea Oliv.). Isanthera permollis Nees was sunk into Rhynchotechum Blume, as R. permolle (Nees) B.L. Burtt (Burtt, 1962a). The genus Klugia Schltdl. was merged into Rhynchoglossum Blume (Burtt, 1962b).

The Indian species of Didissandra C.B. Clarke listed by Clarke (1884) were moved to Corallodiscus Batalin by Burtt (1947). Another Didissandra species (D. muscicola Diels) described from China by Diels (1912) and also collected in Northeast India (Sinha \& Datta, 2016), was moved to Briggsia Craib as B. muscicola (Diels) Craib (Craib, 1919). This species was recently sunk into Oreocharis based on molecular phylogenetic data (Möller et al., 2011b).
One species of Boea Comm. ex Lam., B. multiflora R. Br. was sunk into Paraboea (C.B. Clarke) Ridl., as P. multiflora (R. Br.) B.L. Burtt var. multiflora (Burtt, 1984), but later placed in a new genus Middletonia C. Puglisi (Puglisi et al., 2016). Boea wallichii R. Br. was described from material from upper Burma (Brown, 1839), and is also collected in Northeast India (N.E. Parry 14, K [not barcoded]). Based on molecular phylogenetic evidence it was placed in a new genus, Dorcoceras Bunge, as D. wallichii (R. Br.) C. Puglisi (Puglisi et al., 2016).

Species of Chirita Buch.-Ham. ex D. Don were moved to Henckelia Spreng. (Weber et al., 2011a), one to Microchirita Yin Z. Wang (Wang et al., 2011), and another, C. kurzii (C.B. Clarke) C.B. Clarke to Briggsia, as B. kurzii (C.B. Clarke) W.E. Evans (Evans, 1928). This caulescent species was later returned to Loxostigma C.B. Clarke [i.e. L. kurzii (C.B. Clarke) B.L. Burtt, 1975] for want of a better place for the moment (Möller et al., 2014). 
Molecular data showed that Cyrtandromoea Zoll. is not part of Gesneriaceae and has now been excluded from the family (Weber et al., 2013). All these taxonomic changes resulted in a different set of genera to be present in India. Here, we present an account of these 23 genera as presently occurring in India, all falling in subfamily Didymocarpoideae, in 2 tribes and 9 subtribes (Fig. 1). An identification key, genus descriptions and some considerations on the biogeographic distribution of the genera in India are provided.

\section{Key to the genera native to India}

Notes: (1) For unambiguous identification of some genera both flowering and fruiting material is necessary. (2) In case that the characters given are only relevant for the species in India and not for the genus as a whole, this is explicitly stated. (3) If a genus is represented only by a single species in India, the species name is given in brackets after the genus name; in monotypic genera the specific name is preceded by "only species". In case of most recent taxonomic changes, also the basio- or well-known synonyms are given.

1. Inflorescence a terminal, several- to manyflowered unilateral raceme; flowers in two ranks . . . . . . . . 1. Rhynchoglossum

1. Inflorescence not a terminal raceme; flowers in axillary cymes or solitary . ........... 2

2. Leaves of a pair strongly different in size (anisophyllous), the small leaf scale-like, the large leaf markedly asymmetrical at base; calyx plicate................2. Stauranthera

2. Leaves of a pair subequal or leaves alternate; calyx not plicate . . . . . . . . . . . . 3

3. Inflorescences in terminal and axillary positions, consisting of a stalk, a single denseflowered head (much condensed pair-flowered cyme, flowers in four rows), and a small or conspicuous cucullate subtending bract; fruit a pyxis (capsule with circumscissile dehiscence, bowl-shaped when open) ...... 3. Epithema

3. Inflorescence not as above, usually an axillary pair-flowered cyme or solitary flower, usually scapose in rosette plants; fruit a loculicidally or septicidally dehiscent capsule or indehiscent, hard or fleshy berry $\ldots \ldots \ldots \ldots \ldots \ldots 4$

4. Fertile stamens $4 \ldots \ldots \ldots \ldots \ldots \ldots \ldots$

4. Fertile stamens $2 \ldots \ldots \ldots \ldots \ldots \ldots \ldots$

5. Plants with a single leaf on top of a distinct stalk; leaf heart-shaped, \pm as broad as long, margins coarsely bluntly serrate; stalk $1-2 x$ as long as leaf; inflorescence axillary, with 1 to a few flowers; corolla saintpaulioid, violet, throat whitish; anthers yellow ....10. Platystemma (only species $P$. violoides)

5. Plants with several to many leaves $\ldots \ldots \ldots 6$

6. Plants with leaves in a basal rosette or tuft . . 7

6. Plants with stems with distinct internodes . . 10

7. Filaments flattened, inserted at the middle of corolla tube; two (the shorter ones) with a marked downward appendage; corolla somewhat inflated dorsally, lilac, pencilled with red lines; placentae 4, separate from each other and arising directly from the ovary wall ...... 4. Jerdonia (only species J. indica)

7. Filaments neither flattened nor with appendages; corolla of different colouration; placentae in two lateral pairs .......... . 8

8. Corolla campanulate or short-infundibulifom; anthers cohering all together, poricidally dehiscent; fruits plagiocarpic (held at an angle against pedicel), follicular (opening on the upper side only) ... 7. Beccarinda (B. cordifolia)

8. Corolla tubular, narrow- or broad-tubed; anthers cohering in pairs, longicidally dehiscent; fruits orthocarpic (in \pm straight continuation of pedicel), opening by 2 to 4 valves........ 9

9. Leaves rhomboid; corolla $0.8-1.5 \mathrm{~cm}$ long, tubular, not swollen, bearded on abaxial lip, evenly blue, purple or whitish, not spotted inside ............... 5. Corallodiscus

9. Leaves elliptic to lanceolate; corolla $1.7-3.5 \mathrm{~cm}$ long, broad-tubed, ventrally gibbous, yellow to orange, inside with red-purple to brown markings (these characters apply to the only Indian species of Oreocharis, O. muscicola, and not for the genus as a whole) ... 22. Oreocharis

(O. muscicola, formerly Briggsia muscicola)

10. Plants epiphytic; leaves usually thick-fleshy or leathery; veins usually obscure; corolla with long or short tube, arcuate, usually bright red (more rarely pink, orange, yellow, greenish yellow, greenish or whitish); stamens didynamous, anthers connate in pairs; capsules linear, long; seeds with one or several appendages on one or both tips........... ................. 14. Aeschynanthus

10. Plants terrestrial, if epiphytic (Loxostigma p.p.) characters different (the morphology and taxonomic definition of the following genera are in need of further study; seeds without or with a 
single appendage at each end as in some spp. of Loxostigma . .................... 11

11. Fruit an indehiscent, globose (or slightly 4-parted), white or bluish berry.......... $\ldots \ldots \ldots \ldots \ldots$ 11. Rhynchotechum

11. Fruit a dehiscent brownish capsule. . . . . 12

12. Leaves in a 4-merous whorl on top of stem; flowers crowded in a terminal bunch, almost sessile .....6. Tetraphyllum (T. bengalense)

12. Leaves placed along stem; flowers with distinct pedicels .................. 13

13. Terrestrial or epiphytic herbs with underground rhizome or stem base creeping and rooting; corolla broad-tubular, ventricose; all anthers coherent or coherent in pairs ... 19. Loxostigma

13. Terrestrial shrubs or subshrubs; corolla campanulate; anthers free. . . . . . . . 14

14. Leaves opposite . . . . . . . . . 9. Leptoboea

14. Leaves alternate . . . . . . . . 8. Boeica

15. Fruit indehiscent, a hard (sclerocarpous) "berry" (relevant for the West Malesian species, including the two Indian species from the Great Nicobar Island) . . . . . . . . . . 15. Cyrtandra

15. Fruit a dehiscent capsule. . . . . . . . . 16

16. Capsules (in the Indian species) spirally twisted, 2-valved . . . . . . . . . . 17

16. Capsules straight . . . . . . . . . . . 18

17. Lower leaf indumentum with glands (in the Indian species); corolla campanulate, purple; anthers coherent throughout anthesis. ......

(D. wallichii, formerly Boea wallichii)

17. Lower leaf indumentum without glands; corolla flat, white; anthers coherent only at beginning of anthesis, later free ..........

(M. multiflora, formerly Boea multiflora/Paraboea multiflora)

18. Stigma chiritoid (upper stigma lobe lacking or very short, lower lobe enlarged, often emarginate or bifid) . . . . . . . . . 19

18. Stigma capitate, truncate, stomatomorphic or bilobed (with upper and lower lobe of \pm equal

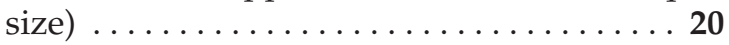

19. Plants annual or short-lived monocarpic, caulescent; inflorescence often crested; fruits bivalved ...........21. Microchirita
19. Plants usually perennial, caulescent or of rosette habit or unifoliate; inflorescence not crested; fruits bivalved or follicular

.................. 18. Henckelia

20. Plants with leaves in basal rosettes; corolla campanulate (in the single Indian species) ........... 23. Petrocosmea (P. parryorum)

20. Plants caulescent (though stem sometimes short); corolla funnel-shaped or infundibuliform.................. 21

21 . Bracts 2 , connate, forming a boat-shaped, semiglobose or urceolate involucre; ovary with one carpel fertile; fruit (in the Indian species) plagiocarpic, follicular (dehiscing only on upper side) ... . 17. Hemiboea (H. subcapitata)

21. Bracts 2, free; ovary with both carpels fertile; fruits orthocarpic, dehiscing on both sides . . 22

22. Plants usually epiphytic; corolla tubularfunnel-shaped, inflated in upper half, mouth often with two folds on lower side, white or purplish, sometimes with yellow spots at the mouth; seeds with a hair-like appendage at each end ........... 20. Lysionotus

22. Plants terrestrial; corolla funnel-shaped or infundibuliform, not inflated, mouth without folds on lower side, not spotted; seeds unappendaged ........ 16. Didymocarpus

\section{Descriptions of the genera native to India}

In the following, descriptions of genera are given in taxonomic order according to the new family classification for Gesneriaceae (Weber et al., 2013), providing generic characters valid for the entire genus. Genera from elsewhere, with the one or other species naturalized in India, are not considered. The species numbers given here for the genera are taken from the World Checklist of the Smithsonian Institution (Skog \& Boggan, 2007), and updated with new entries from The International Plant Names Index (2012; accessed 10 February 2017). They represent a rough guide only, since ongoing taxonomic work will likely affect these numbers in the future for some genera.

I. Tribe Epithemateae C.B. Clarke

There are no changes in this tribe at the generic level and India retains its three genera, Rhynchoglossum (subtribe Loxotidinae G. Don), Stauranthera Benth. (subtribe Loxoniinae A. DC.), and Epithema Blume (subtribe Epithematinae DC. ex Meisn.).

Subtribe Loxotidinae G. Don 
1. Rhynchoglossum Blume (incl. Klugia Schltdl.)

(Fig. 2a \& b)

Perennial or annual herbs, glabrous or with sparse indumentum of many-celled, often branched, eglandular hairs. Stems terete, fleshysucculent with medullary bundles. Leaves alternate, nearly distichous, shortly petiolate, laminae obliquely ovate-cordate, base strongly asymmetrical. Inflorescences terminal, unilateral racemes with two flower rows, subtending bracts small, linear, mostly displaced onto the pedicels, a few sterile bracts often present on the flowerless side of the inflorescence axis. Sepals connate in the lower half, sometimes with wings at the lines of fusion, lobes narrowly triangular-acute. Corolla usually white (esp. tube) and azure blue (corolla lobes), rarely deep purple or evenly white, typically strongly zygomorphic; tube cylindrical, upper lip (in most species) of two short, upright or reclined lobes, lower lip a large, roundish or elongate, entire or slightly three-partite plate or tongue, rarely limb consisting of five subequal lobes. Fertile stamens 4 (the former genus Klugia) or 2; filaments inserted near middle of corolla, anthers coherent in pairs, thecae parallel or divaricate, apically confluent, dehiscing longicidally. Ovary unilocular. Capsules globose or ovoid, included in the calyx, dehiscing loculicidally.

Note: About 16 spp.; from $\mathrm{N}$ and $\mathrm{S}$ India and $\mathrm{S}$ China to New Guinea, and $1 \mathrm{sp}$. (or more?) in C America. 3 or 4 spp. in India.

Subtribe Loxoniinae A. DC.

\section{Stauranthera Benth. (Fig. 2c \& d)}

Perennial (sometimes annual?) herbs with fleshysucculent stems. Leaves opposite, strongly anisophyllous, large leaves obliquely elliptic or ovate, base very unequal, apex acute-acuminate or blunt; small leaves reduced to a tiny cordior reniform auricle. Inflorescences terminal, an alternicladic thyrse with pair- or singleflowered cymes or solitary flowers emerging from small bracts. Sepals with conspicuous plications at the sinuses. Corolla blue or white, sometimes with a yellow blotch at the palate, either rotate or widely campanulate, ecalcarate, or distinctly zygomorphic and spurred at the base. Stamens 4; filaments adnate to corolla base; anthers coherent and forming a crosslike figure, thecae slightly divergent, dehiscing longicidally. Nectary absent. Ovary unilocular. Capsules globose, breaking irregularly into pieces in the upper half.
Note: 7 spp.; from NE India and S China throughout Malesia to New Guinea. 2 spp. in India.

Subtribe Epithematinae DC. ex Meisn.

\section{Epithema Blume (Fig. 2e \& f)}

Monocarpic herbs with succulent stems. Typical morphology (relevant also for the Indian species): Cotyledons basal, appearing at ground level, the macrocotyledon developing into a large petiolate leaf that falls off early and is usually no longer present in the flowering plant; lowermost cauline leaf solitary with distinct petiole and broadly ovate-cordate laminae; upper leaves smaller, opposite (more rarely alternate), in one or two pairs, subsessile or petiolate. Inflorescences one to many, consisting of a stalk, a single densely contracted headlike pair-flowered cyme and its subtending bract; bract of variable size and form, ranging from large, cucullate and enclosing the flowerhead to a small scale. Sepals connate in lower half, lobes triangular, spreading after anthesis and the calyx forming a campanulate rain splash cup. Corolla bluish or white with blue or purple patches on the upper lobes; tube cylindrical; limb bilabiate. Nectary cup-shaped. Fertile stamens 2, the posterior pair; filaments inserted above middle of corolla tube; anthers apically coherent, thecae divaricate, apically confluent; staminodes 2, their filaments longer than those of the fertile stamens, distal parts upcurved. Ovary unilocular. Capsules globose, membranous, dehiscence circumscissile.

Note: The genus was recently revised by Bransgrove \& Middleton (2015). 20 spp.; from N India and S China over SE Asia to New Guinea, 1 sp. in W Africa, and 3 spp. in India.

\section{Tribe Trichosporeae Nees}

In this tribe, three monogeneric subtribes were established, subtribe Jerdoniinae A. Weber \& Mich. Möller to accommodate Jerdonia Wight, subtribe TetraphyllinaeA.Weber\&Mich.MöllerforTetraphyllum Griff. ex C.B. Clarke and subtribe Corallodiscinae A. Weber \& Mich. Möller for Corallodiscus. All occur in India. Subtribe Leptoboeinae C.B. Clarke includes six genera that retain their original circumscriptions. All, except Championia Gardner, occur in India. Subtribe Loxocarpinae A. DC., after re-circumscription of several of its genera, now includes 14 genera, with only Dorcoceras and Middletonia occurring in India. Subtribe Didymocarpinae G. Don is the largest in tribe Trichosporeae, presently comprising 32 genera (Möller et al., 2016), and species of 9 genera occur in India. 




Fig. 2. Photographic images of Gesneriaceae occurring in India and adjacent areas. a, b. Rhynchoglossum notonianum (Wall.) B.L. Burtt: a. Habit; b. Flower; c, d. Stauranthera grandiflora Benth., Malaysia: c. Flowers; d. Habit; e, f. Epithema zeylanicum Gardner: e. Habit; f. Flower; g-i. Jerdonia indicaWight: g. Flower, h. Immature capsules; i. Habit; j, k. Corallodiscus lanuginosus (Wall. ex DC.) B.L. Burtt: j. Habit; k. Flower; I, m. Beccarinda cordifolia (J. Anthony) B.L. Burtt: I. Plagiocarpic fruits; m. Habit. (Images: a, e-g: A.P. Janeesha \& S. Nampy, University of Calicut; c, d: A. Weber, University of Vienna; b, h, i: M. Möller, RBGE; j, k: V.S. Hareesh \& P.G. Arunkumar, University of Calicut; I-m: G. Krishna, Central National Herbarium (CAL), Botanical Survey of India. All with permission). 
Subtribe Jerdoniinae A. Weber \& Mich. Möller

\section{Jerdonia Wight (Fig. 2g-i)}

(Sub)-rosette perennials. Leaves alternate, long-petiolate, laminae elliptic. Cymes longpedunculate, few-flowered; bracts small. Sepals free, lanceolate. Corolla pale lilac with red lines; tube elongate, inflated above; limb oblique, bilabiate; lobes ovate, obtuse. Stamens 4; filaments short, dilated upwards, two with distinct spurs, inserted in the middle of the corolla tube; anthers connivent and coherent at the apices; thecae divergent, apically confluent. Nectary annular. Ovary ovoid, unilocular with 4 parietal placentae; style slender; stigma small, obscurely bilobed. Capsules broadly ovoid, loculicidally dehiscing. Seeds ellipsoid, testa striate-reticulate with longitudinal furrows (slightly star-shaped in cross section).

Note: In molecular phylogenies, J. indica Wight occupies a basal lineage in tribe Trichosporeae (Möller et al., 2009) and has unusual morphological features such as apparently isocotylous seedlings, as opposed to anisocotylous seedlings of most Old World Gesneriaceae (Burtt, 1963), a corolla with a prominent boss, conspicuously inflated on the adaxial side [somewhat reminiscent of the recently established genus Tribounia D.J. Middleton (Middleton \& Möller, 2012)], flattened and appendaged filaments and unilocular ovary with four separate placentae (Wight, 1850; Weber, 1989; Janeesha \& Nampy, 2014). Only one species (J. indica Wight) in India.

Subtribe Corallodiscinae A. Weber \& Mich. Möller

\section{Corallodiscus Batalin (Fig. 2j \& k)}

Perennial rosette herbs. Leaves many, glabrous to densely woolly, laminae broadly lanceolate, (ob)ovate, rhombic, elliptic or suborbicular, base broadly or narrowly cuneate; venation conspicuous. Cymes one- to many-flowered, lax or rarely subumbellate; bracteoles apparently absent. Sepals free or fused halfway. Corolla blue to purple, rarely yellow or white, tubular, limb bilabiate; upper lip shorter than lower lip; lobes subequal, rounded or obtuse; lower lip with dense beard inside of tube. Stamens 4, inserted above corolla base (rarely above middle), included or slightly exserted; anthers dorsifixed, coherent in pairs; thecae divaricate, confluent, longicidally dehiscent. Nectary annular. Ovary oblong; stigma capitate. Capsules oblong to linear, much longer than the calyx, dehiscing loculicidally, sometimes also septicidally.
Note: The genus has only a few species with mostly limited distribution in Bhutan and China, except for C. lanuginosus (Wall. ex DC.) B.L. Burtt that has an extremely wide distribution, ranging from Beijing Municipality in NE China to S India (Wang et al., 1998). Interestingly, C. lanuginosus was only recently recorded from the Western and Eastern Ghats in India (Kamble et al., 2006; Rout et al., 2008). 5 spp.; Bhutan, China, $\mathrm{N}$ and NE India, Nepal, Thailand. 2 spp. in India.

Subtribe Tetraphyllinae A. Weber \& Mich. Möller

\section{Tetraphyllum Griff. ex C.B. Clarke}

Perennial herbs with monocarpic stem(s). Stems erect, caulescent, tawny-villose, bearing a tetramerous (pseudo)whorl or a single leaf pair at the top and pairs of scale leaves (in some species with axillary cymes) along the stem. Leaves petiolate or (sub)sessile, laminae ovate or lanceolate, partly unequal-sided. Cymes condensed, flowers nearly sessile; bracteoles small. Sepals 5, almost free to base. Corolla pink or blue, widely funnel-shaped; limb bilabiate or subregular; lobes obtuse. Stamens 4, didynamous, or 2; filaments adnate to corolla base; anthers coherent at the tips, opening by longitudinal slits. Nectary much-reduced. Ovary ovoid; stigma obscurely bilobed. Capsules splitting loculicidally and septicidally into 4 valves, leaving the two main ribs united to the persistent style base.

Note: 3 spp.; NE India, Bangladesh(?), Myanmar, Vietnam, Thailand. 1 sp. (T. bengalense C.B. Clarke) in India.

Subtribe Leptoboeinae C.B. Clarke

\section{Beccarinda Kuntze (Fig. 21 \& m)}

Perennial herbs, rarely subshrubs. Stemless with basal leaves or with leafy unbranched stem. Indumentum of white, fawn, brown or reddish purple hairs. Leaves petiolate, laminae elliptic or ovate to ovate-orbicular, base cordate. Cymes pedunculate, umbelliform or pseudocapitate. Sepals 5, free to base. Corolla purple-blue or red, campanulate, bilabiate. Stamens 4, inserted near corolla base, included; anthers all coherent, thecae subparallel, apically confluent, dehiscing poricidally. Nectary ring-like or inconspicuous. Ovary ovoid; stigma capitate. Capsule at an angle to the pedicel, straight, ovoid to oblong, opening on the upper side.

Note: Around 8 spp.; NE India, Myanmar, S China, Laos, Vietnam (Tonkin), Indonesia (Sumatra). $1 \mathrm{sp.}$ [B. cordifolia (Anthony) B.L. Burtt] in India. 


\section{Boeica C.B. Clarke (Fig. 3a \& b)}

(Sub)shrubsor perennialrhizomatousherbs. Leaves alternate, spaced along stem, tufted at apex or forming a basal rosette, petiolate, laminae (ob)ovate to elliptical, base cuneate or attenuate, glabrous to densely woolly. Cymes lax or dense, one- to manyflowered. Sepals free or fused halfway. Corolla white to pink or blue to purple, campanulate or flat-faced, limb slightly zygomorphic; lobes (sub) equal, rounded or acute. Stamens 4 , inserted near corolla base; filaments short; anthers large, free, basifixed, thecae subparallel, apically confluent; dehiscence variable. Nectary ring-like or lacking. Ovary ovoid or conical; stigma capitate. Capsules short to linear with persistent style, loculicidally and then septicidally dehiscent.

Note: 14 spp. described, but probably fewer. Bhutan, S China, N and NE India, Myanmar, N Vietnam, NW Malaya. 4 spp. in India.

\section{Leptoboea Benth. (Fig. 3e \& f)}

Terrestrial shrubs with branched stems; branches spongy. Leaves opposite, those of a pair equal or subequal; petioles short, laminae ovate, apex acute, base broadly cuneate. Cymes with filiform peduncles and pedicels, 3-5-flowered, umbellate. Sepals free, equal. Corolla whitish with two purple spots at base of upper lobes, shallowly campanulate, tube slightly longer than limb, limb obscurely bilabiate; lobes (sub)equal, rounded. Stamens 4, inserted at corolla base, included; anthers free, basifixed, thecae subparallel, apically confluent, dehiscing poricidally. Nectary absent. Ovary ovoid; stigma capitate. Capsules linear, much longer than the calyx, dehiscence septicidal, eventually also loculicidal.

Note: 2 spp. validly described, but perhaps only 1. Bhutan, $\mathrm{N}$ and NE India, S China, Myanmar, Nepal, Thailand. 2 spp. in India.

\section{Platystemma Wall. (Fig. 3c \& d)}

Small slender herbs with a horizontal rhizome (with a successive series of tuberous swellings). Aerial shoots with a single, sessile, orbicularcordate, membranous, hairy leaf. Cymes emerging from the leaf axil; peduncle slender, bearing one to a few flowers; bracteoles very small, sublinear. Sepals free nearly to base, forming a wide, campanulate calyx. Corolla violet, tube whitish, short, limb wide, deeply bilabiate; lobes oblong, obtuse. Stamens 4; filaments short, curved; anthers apically coherent; thecae divaricate, apically confluent, dehiscing by a single short slit. Nectary annular. Ovary ovoid; style much longer than ovary; stigma inconspicuous. Capsules ovoidoblong, splitting loculicidally (+ septicidally?), partially enclosed in the persisting calyx.

Note: 1 sp. (P. violoides Wall.); Nepal, Bhutan, N India and SW China.

\section{Rhynchotechum Blume (Fig. 3g \& h)}

Shrubs or subshrubs. Stem erect, woody, unbranched or branched. Leaves opposite or alternate, (sub)equal in a pair when they are opposite, surface woolly, hirsute or glabrescent. Cymes (few- to) many-flowered, lax. Sepals 5, free, equal. Corolla white, cream, or pinkpurple to red-maroon, tubular-campanulate, limb slightly bilabiate; lobes rounded. Stamens 4 , included, inserted near the base or in the middle of the corolla; anthers free, thecae parallel, apically confluent, dehiscing longicidally. Nectary ringshaped or absent. Ovary ovoid; stigma globose. Berry ovoid or globose.

Note: The genus was revised by Anderson \& Middleton (2013). 16 spp.; India, Sri Lanka, Nepal, Bangladesh, Bhutan, SW and S China, Taiwan, Japan, SE Asia to New Guinea. The genus has its main distribution in India in the NE with 7 species, but extends with 2 species, R. permolle and R. parviflorum Blume, to $\mathrm{S}$ India and the Nicobar Islands, respectively.

Subtribe Loxocarpinae A. DC.

\section{Dorcoceras Bunge}

Plants with leaves in rosette. Leaves opposite or alternate, indumentum simple on the upper surface and glandular or eglandular on the lower surface. Cymes axillary. Sepals 5, free. Corolla lilac-blue, obliquely campanulate with a ventricose tube, reflexed upper lobes and a broad throat. Stamens 2 , included in the throat, erect; filaments slender. Capsules 2-valved, spirally twisted.

Note: The genus has been resurrected to accommodate four species segregated from Boea. The species are distinguished from Boea by their rosette habit (vs. caulescent), and campanulate corolla (vs. flat-faced corollas) with inserted stamens (vs. exserted stamens) (Puglisi et al., 2016). 4 spp.; China, Thailand, Cambodia, Vietnam, Philippines, India and Indonesia. $1 \mathrm{sp}$. [D. wallichii (R. Br.) C. Puglisi, the former Boea wallichii R. Br.] in India.

\section{Middletonia C. Puglisi (Fig. 3i-k)}

Perennial herbs. Leaves opposite; laminae oblong to elliptic, base cuneate to rounded, sometimes oblique, margins crenate or serrate, apex obtuse 


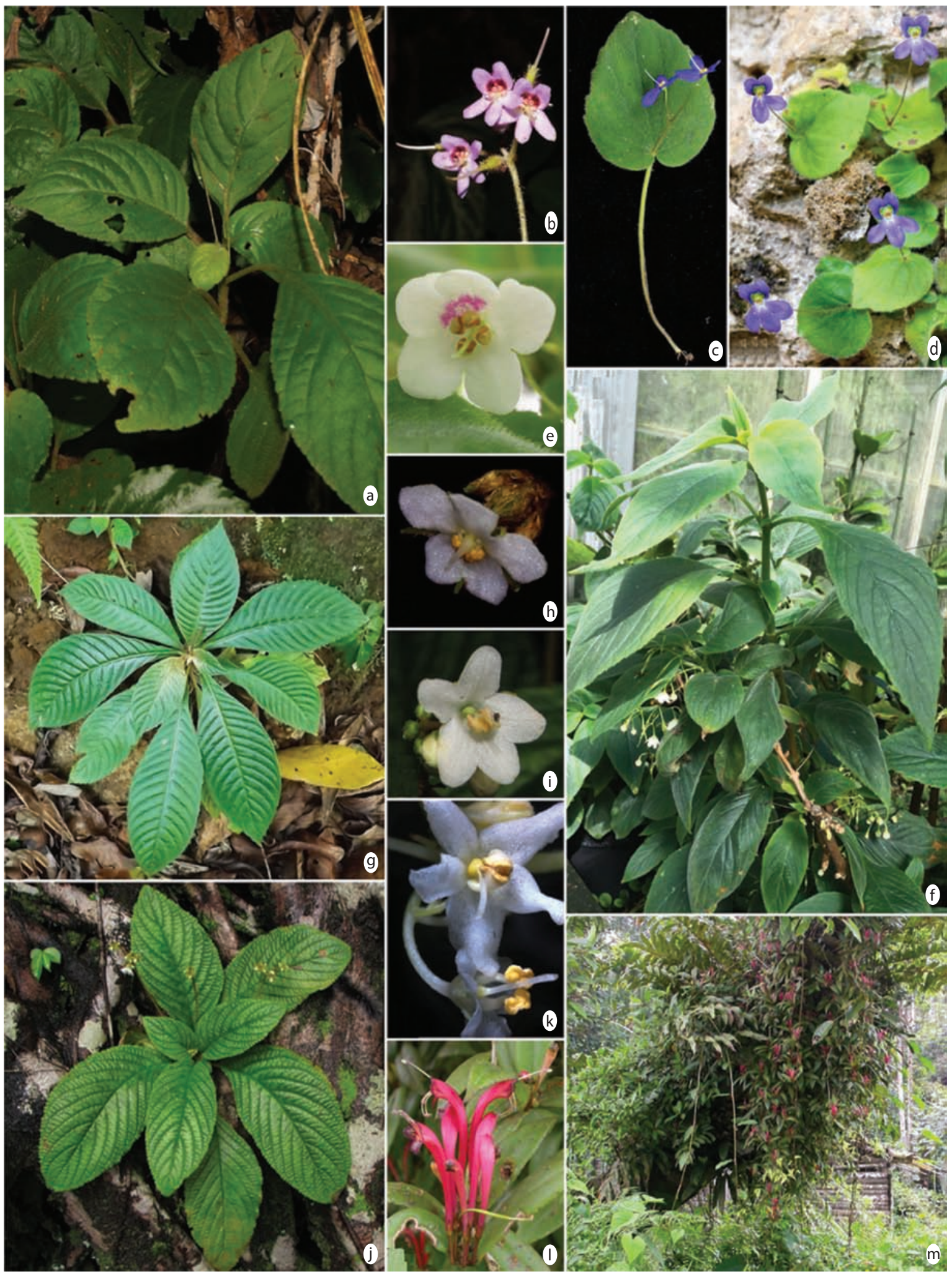

Fig. 3. Photographic images of Gesneriaceae occurring in India and adjacent areas. a, b. Boeica sp.: a. Habit; b. Flowers; c,d. Platystemma violoides Wall., Nepal; c. Individual plant; d. Habit; e, f. Leptoboea multiflora (C.B. Clarke) Gamble, Thailand: e. Flower; f. Habit; g, h. Rhynchotechum permolle (Nees) B.L. Burtt: g. Habit; h. Flower; i, j. Middletonia multiflora C. Puglisi: i. Flower; j. Habit; k. Middletonia sp. nov., Thailand, flowers showing non-adhering anthers (lower fl.); I, m. Aeschynanthus ceylanicus Gardner: I. Flowers; m. Habit. (Images: a, b: Gopal Krishna, Central National Herbarium (CAL), Botanical Survey of India; c, d: Bhaskar Adhikari, RBGE; e, f, k-m: Michael Möller, RBGE; g, h: Janeesha A.P \& S. Nampy, University of Calicut; i, j: Alfred Joe, Department of Botany, University of Calicut. All with permission). 
to acute; upper surface glabrescent, furfuraceous or pubescent, lower surface with a matted indumentum; veins raised beneath. Cymes axillary, many-flowered, densely tomentose; bracts inconspicuous. Sepals 5, free to base; narrowly ovate, glabrous or glandular inside, \pm tomentose outside. Corolla white, violet or blue, slightly bilabiate, with or without indumentum; tube short; limb slightly 2-lipped, upper lip 2-lobed, lower lip 3-lobed, lobes spreading, flat. Stamens 2; anthers with a minute, glandular indumentum, coherent when young, later free, opening towards the top. Ovary ovoid with a farinose glandular indumentum, style glabrous; stigma capitate. Capsules straight or twisted, retaining the indumentum of the ovary.

Note: Middletonia was established for a few species previously belonging to Paraboea. Middletonia and Paraboea s.str. are similar in their matted indumentum on the abaxial side of leaves, but the former possesses a farinose glandular indumentum on the ovary. The farinose glands extend to the anther inner faces and corolla outer surfaces. Middletonia has been described as having free and erect anthers (Puglisi et al., 2016). On closer study, however, the anthers proved coherent in early stages, but become later free and present pollen rather openly, at least in an as yet undescribed taxon growing in Edinburgh (RBGE-BG-Base acc. no.: 20121408, coll. no. D.J. Middleton 5559) from Thailand (M. Möller, pers. obs.). Whether this characteristic is common to all species in Middletonia requires further detailed field studies. 4 spp.; N India, Bangladesh, Bhutan, S China, Burma, Thailand, Laos, Cambodia, Vietnam, Malaysia. 1 sp. [M. multiflora (R. Br.) C. Puglisi, the former Boea multiflora R. Br. and Paraboea multiflora (R. Br.) B.L. Burtt] in India.

\section{Subtribe Didymocarpinae G. Don}

\section{Aeschynanthus Jack (Fig. 31 \& m)}

Epiphytic (rarely terrestrial) (sub)shrubs. Stems terete, rarely (sub)quadrangular, branched or not, erect, spreading or pendulous; clinging to the substrate by nodal roots. Leaves opposite, often arranged in a single plane, rarely whorled; petioles short, laminae (linear to) lanceolate, ovate, or cordate (to suborbicular), margins entire, rarely obscurely denticulate; fleshy or leathery or rarely herbaceous, sometimes with a water-storing hypodermis below the upper epidermis; veins usually obscure. Inflorescence a few-flowered, axillary cymes or flowers solitary, in leaf axils or emerging from scaly bracts and forming a pseudoterminal cluster; bracteoles ovate or scaly, rarely large and coloured, usually deciduous. Sepals either free and linear, or basally fused or entirely connate to form a cup-shaped or cylindrical, often showy (coloured) calyx with small rounded lobes. Corolla usually bright red, or rarely orange, yellow, greenish yellow or greenish; tube usually long, arcuate; limb bilabiate, often with dark spots or stripes; lobes rounded. Stamens 4, didynamous, included or exserted; anthers coherent in pairs at the tips, rarely all four coherent. Nectary ring- or cup-shaped. Ovary stipitate, linear; stigma capitate or peltate. Capsules linear, in some species up to $50 \mathrm{~cm}$ long, loculicidally dehiscent. Seeds with a triangular appendage at both ends or a filiform appendage at the apical and one to many filiform appendages at the hilar end.

Note: >166 spp.; from India and S China throughout Malesia to New Guinea and the Solomon Islands. The genus was recently revised for Thailand (Middleton, 2007), and Cambodia, Laos and Vietnam (Middleton, 2009), and c. 15 species were recognized for India, while Bhattacharyya \& Goel (2014) recognized 26 species [many species were synonymized by Middleton $(2007,2009)]$. Sinha \& Dutta (2016) reported 16 species from NE India, which included $A$. angustioblongus W.T. Wang and A. philippinensis C.B. Clarke, not mentioned by Bhattacharyya \& Goel (2014). Clearly the genus requires additional work in India.

\section{Cyrtandra J.R. Forst. \& G. Forst.}

Lignescent herbs, shrubs or small trees. Stems terete or angular, erect or ascending, branched or unbranched. Leaves opposite, iso- to strongly anisophyllous, petiolate; laminae ranging from narrowly lanceolate to suborbicular, margins entire or dentate; venation pinnate. Cymes short- to long-pedunculate, placed in upper or lower (leafless) part of stem, sometimes growing underground; bracteoles free or connate and forming a conspicuous cup; flowers in dense clusters or in open cymes or solitary. Calyx lobes 5, free or connate, sometimes bilabiate, persistent or caducous. Corolla variously (usually light) coloured, funnelform, campanulate or tubular; limb bilabiate, rarely (sub)-regular; lobes rounded. Stamens usually 2, rarely 4; included or (rarely) exserted; anthers free or coherent, thecae subparallel, sometimes apically confluent, dehiscing longicidally. Nectary ring- or cupshaped. Ovary ovoid to oblong, stigma capitate or bilobed. Fruits indehiscent, oblong, ovoid or globose, hard-walled, leathery or fleshy.

Note: 652-818 spp. (Atkins et al., 2013); from the Nicobar Islands, S China and S Japan throughout 


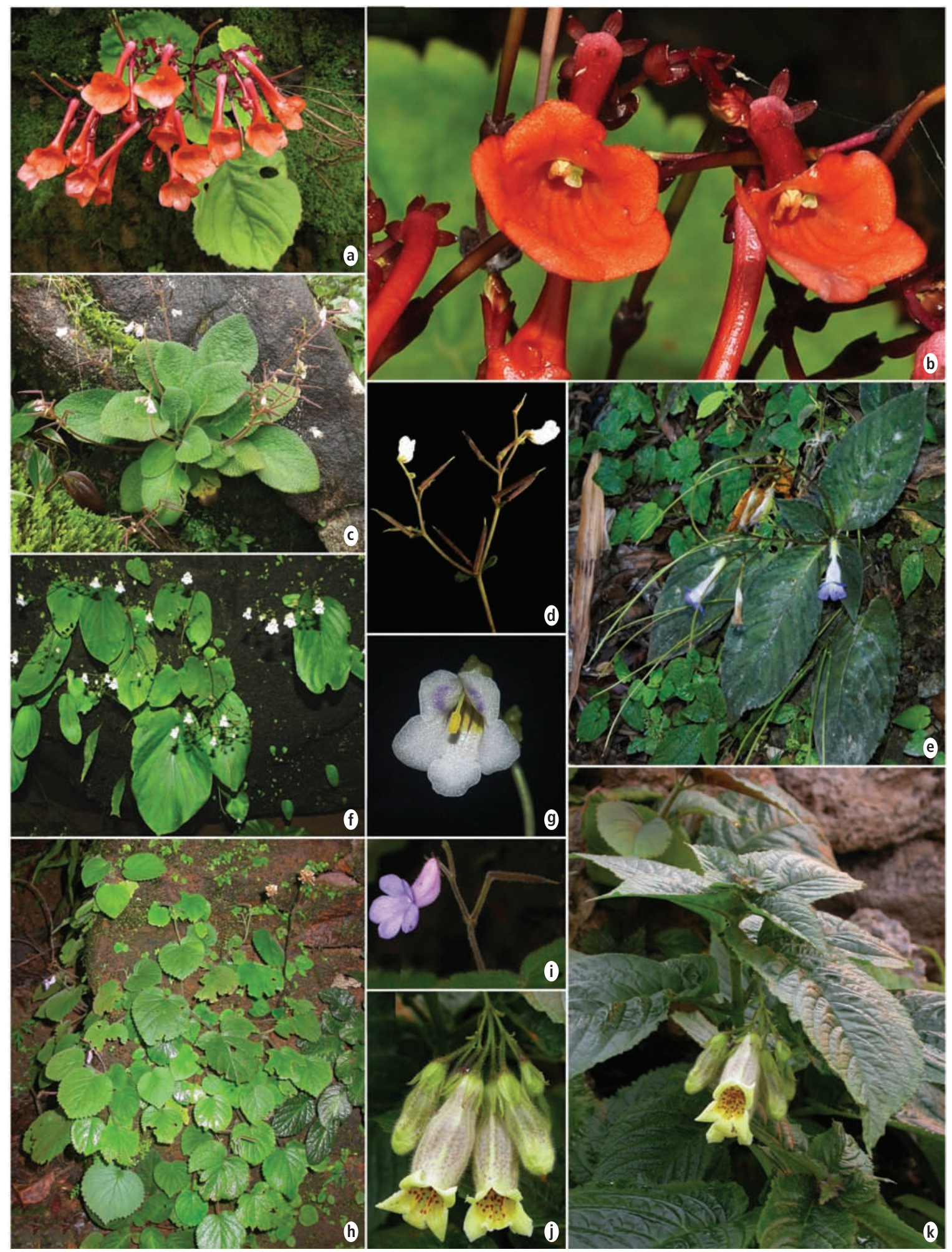

Fig. 4. Photographic images of Gesneriaceae occurring in India and adjacent areas. a, b. Didymocarpus moellerii A. Joe, Hareesh \& M. Sabu: a. Habit and flowers; b. Flowers showing enanthiostyly; c, d. Henckelia bracteata Janeesha \& Nampy: c. Habit; d. Flowers and immature fruits; e. Henckelia pumila (D. Don) A. Dietr., habit; f, g. Henckelia pradeepiana Nampy, Manudev \& A. Weber: f. Habit; g. Flower; h, i. Henckelia repens (Bedd.) A. Weber \& B.L. Burtt: h. Habit; i. Flower; j, k. Loxostigma griffithii (Wight) C.B. Clarke, Nepal: j. Flowers; k. Habit. (Images: a, b: Alfred Joe, Department of Botany, University of Calicut; c, d, f, g: A.P. Janeesha \& S. Nampy, University of Calicut; e: P.G. Arunkumar \& A.P. Janeesha, University of Calicut; h-k: Michael Möller, RBGE. All with permission). 
Malesia and the Pacific to the Hawaiian Islands. Cyrtandra is the largest genus of Gesneriaceae and has the widest distribution in the Old World. Centres of diversity are Borneo, New Guinea and the Pacific Islands. 2 spp. in India (Great Nicobar Island).

\section{Didymocarpus Wall. (Fig. 4a \& b)}

Perennial terrestrial or saxicolous, caulescent herbs. Stems seasonal, herbaceous, erect with few nodes; renewal buds produced in the humid season, are dormant in the dry season and develop into flowering shoots in the next humid season. Leaves decussate, in few pairs on short stem, in the tropical (Malayan) species leaves in several distant pairs on long stem. Cymes pedunculate, few- to many-flowered. Bracts 2, free, opposite. Sepals free or connate halfway or more, cartilaginous, surface polished. Corolla often claret-coloured or violet, but including a wide range of colours, usually straight tubular or trumpet-shaped, widening towards the mouth; limb slightly to strongly bilabiate, rarely personate; lobes rounded. Stamens 2, included; filaments slender; anthers cohering. Nectary cup-shaped, rim sometimes lobed. Ovary cylindrical; stigma capitate. Capsules usually stipitate, bivalved, dehiscing loculicidally.

Note: The genus still requires taxonomic adjustments with some Chinese species, which are likely to be excluded on the basis of recent molecular studies (Weber \& Burtt, 1998; Möller et al., 2011a; Li et al., 2016). Around 98 spp.; N and NE India, Nepal and S China southwards to the Malay Peninsula and N Sumatra. 23 spp. in India, including the recently described D. moellerii A. Joe, Hareesh \& M. Sabu (Joe et al., 2016). These are essentially restricted to the NE, with only one, D. lyratus var. protractus C.B. Clarke occurring in the southern region which clearly belongs to Henckelia, though the variety was not formally transferred to that genus by Weber \& Burtt (1998).

\section{Hemiboea C.B. Clarke}

Perennial caulescent herbs with erect stems. Leaves opposite, petiolate; laminae ovate or lanceolate. Cymes in the axils of the uppermost leaves, severalto many-flowered; flowers enclosed by large, connate bracteoles forming a boat-shaped, semiglobose or urceolate involucre. Sepals connate in lower part, 3-veined. Corolla white, pale yellow or rose to purple coloured, funnel-shaped; limb bilabiate, upper lip 2-lobed, lower lip 3-lobed; lobes rounded. Stamens 2, inserted above base or below middle of corolla tube; filaments slender or filiform; anthers apically coherent, thecae parallel, not confluent; staminodes 2 or 3 . Nectary annular.
Ovary slender, cylindrical, bilocular, only upper (adaxial) locule fertile; stigma truncate or capitate. Capsules oblique in relation to pedicel (sometimes straight?), cylindrical, somewhat curved upwards, dorsally (sometimes on both sides?) dehiscent.

Note: Based on molecular studies, the genus was expanded to include the only two described species of Metabriggsia W.T. Wang (Weber et al., 2011b); plus a few recently described species. 33 spp.; NE India, C \& S China, Taiwan, N Vietnam, Japan. 1 sp. (H. subcapitata C.B. Clarke) in India.

\section{Henckelia Spreng. (Fig. 4c-i)}

Perennial (rarely annual), caulescent or rosette or rarely creeping herbs. Leaves opposite, alternate or whorled, sometimes clustered at the stem apex, petiolate; lamina shape variable, sometimes pinnately lobed. Cymes axillary, 1-15-flowered; bracts paired or in whorls, free or connate at base, sometimes early caducous. Sepals 5, free or fused into a tube for part of length, triangular or narrowly triangular. Corolla colouration variable, often with yellow markings in throat, infundibuliform, more rarely tubular; tube often slightly pouched, sometimes rather constricted in throat; bilabiate with 2-lobed upper lip and 3-lobed lower lip. Stamens 2; filaments geniculate or straight; anthers fused face to face, glabrous or pubescent. Disk a simple annular ring or 5-lobed, often very small. Ovary shortly stipitate or not; stigma chiritoid, often weakly so and rarely almost truncate, lower lobe bifid or not. Capsules splitting into 2 valves or opening only along the dorsal side, stipitate or not, plagiocarpic or orthocarpic, calyx persistent or not in fruit. Growing on acidic soils and rocks, not on limestone.

Note: The amalgamation of Henckelia sect. Henckelia (sensu Weber \& Burtt, 1998), the species of Chirita sect. Chirita, and the monotypic genus Hemiboeopsis W.T. Wang (Weber et al., 2011a) changed the morphological concept of the genus enormously and partly introduced rather unusual characters.

In India, there are basically two groups of species in Henckelia, corresponding to species previously belonging to Chirita sect. Chirita (predominantly with caulescent habit with internodes and leaves in whorls of 2 or 3 and orthocarpic capsules dehiscing along both upper and lower suture) in the NE (and Sri Lanka) and those of Henckelia sect. Henckelia (predominantly with leaves in a basal rosette and plagiocarpic capsules opening along the upper suture only) in S India. The latter were initially placed in Didymocarpus (as sect. Orthoboea Benth., see Weber \& Burtt, 1998), but can be distinguished from Didymocarpus s. str. by growth patterns, with 
Didymocarpus showing seasonal growth with dormant buds surviving the dry season, which is absent in Henckelia, and the mostly capitate, or obscurely bilobed stigma and enantiostyly (the deflection of the style either to the left or right side of the floral axis) in Didymocarpus. Both groups of Henckelia have a chiritoid stigma (i.e., the absence of an upper and the usually bifid development of the lower stigma lobe) and mirror-image flowers (i.e., absence of enantiostyly). About 60 species including the recently described $H$. pradeepiana Nampy \& al. (Manudev et al., 2012), H. bracteata Janeesha \& Nampy (2015) from Kerala, and $H$. sivagiriensis (Rajakumar, Selvak., S. Murug. \& Chellap.) E.S.S. Kumar from Tamil Nadu (Kumar, 2013). NE and S India, Sri Lanka, Nepal, Bhutan, S China, Northern Vietnam, N Laos, N Thailand. 32 species in India.

\section{Loxostigma C.B. Clarke (Fig. 4 j \& k)}

Terrestrial or epiphytic herbs with underground rhizome or the lower part of the stem creeping and rooting. Leaves usually opposite, strongly anisophyllous, membranous; internodes sometimes condensed, giving the appearance of irregular pseudo-whorls of leaves. Cymes pedunculate; flowers 1 or 2 to many. Sepals free or almost free to base. Corolla white, yellow to orange, lavender or purple, inside often red purple or brownish spotted, tubular, ventricose in the middle, spotted within. Stamens 4, slightly didynamous; filaments inserted at base or near middle of corolla tube, curved; anthers equal, cohering by their tips either in pairs or all together. Nectary cupular. Ovary sessile, elongate; stigma obliquely bilamellate. Fruits sessile, somewhat compressed laterally, dehiscing loculicidally. Seeds with or without an appendage at each end.

Note: The definition of Loxostigma has slightly widened with the inclusion of caulescent species of the former genus Briggsia into Loxostigma, including the resurrection of the Indian Loxostigma kurzii (Möller et al., 2014). Until then, the main difference between caulescent Briggsia species and Loxostigma was seen in the possession of appendaged seeds in the latter (Wang et al., 1998; although seeds are unknown for half of the species listed in the Flora of China). The inclusion of the Briggsia species was necessary for nomenclatural stability reasons, since the type of Briggsia, B. longifolia Craib, had been sunk in Oreocharis (Möller et al., 2011b). Consequently, Loxostigma now includes species with and without appendaged seeds. 11 spp.; NE India, Bhutan, Nepal, Myanmar, S China, Laos, N Vietnam. 2 spp. in India.

\section{Lysionotus D. Don (Fig. 5a \& b)}

Epiphytic herbs or subshrubs. Stems branched, branches \pm woody, glabrous. Leaves opposite or in whorls of three, isophyllous or unequal in size, herbaceous or coriaceous; petioles short; laminae lanceolate or elliptical-acuminate, margins entire to crenate-serrate. Cymes pedunculate, few- to manyflowered; bracteoles inconspicuous. Sepals almost free, rarely fused halfway. Corolla white, yellow or purplish to reddish, infundibuliform; tube straight, inflated in upper half; limb slightly bilabiate, mouth (always?) with two yellow folds; lobes rounded. Stamens 2, included; filaments flattened and curved; anthers cohering face to face, connective sometimes with an appendage, thecae sub-parallel. Nectary annular. Ovary (sub)-stipitate, cylindrical; stigma slightly bilamellate. Capsules cylindrical, splitting loculicidally (later also septicidally). Seeds with a hair-like appendage at the apical end and a capillary funicle at the hilar end.

Note: 29 spp.; from N India and Nepal eastwards through S China, Taiwan, Bhutan, Laos, Myanmar, N Thailand, N Vietnam to S Japan. 6 spp. in India.

\section{Microchirita (C.B. Clarke) Yin Z. Wang (Fig. 5c \& d)}

Mostly annual (more rarely longer lived in a \pm aseasonal climate or dying down to a rootstock in the dry season of more seasonal climates), caulescent, rarely creeping. Stems often fleshy or juicy. Leaves in distant pairs, except lowermost leaf solitary (macrocotyledon). Inflorescences usually two or several in a leaf axil, often displaced onto the petiole, often consisting of a short-stalked serial flower pair only, but this repeated several times (serial arrangement, "crested inflorescence"). Sepals free to base, narrowly triangular to narrowly ovate, appressed to fruit. Corolla white, bluish, blue, purple, yellow, orange or reddish, usually infundibuliform, tubular or funnel-shaped; upper lip 2-lobed, lower lip 3-lobed; lobes rounded. Stamens 2; anthers usually joined. Stigma chiritoid. Capsules elongate, straight or curved, usually splitting into 2 valves.

Note: Microchirita, as a previous member of Chirita, the erstwhile C. sect. Microchirita C.B. Clarke, shares the chiritoid stigma (the main character for the hitherto genus Chirita) with other genera previously associated with Chirita, such as Damrongia Kerr, Liebigia Endl., and Primulina Hance (see Weber et al., 2011a). Microchirita is well defined and readily characterised by its caulescent habit (though some species remain in a unifoliate state under adverse conditions), with decussate leaves, almost free sepals, more or less tubular corolla, 


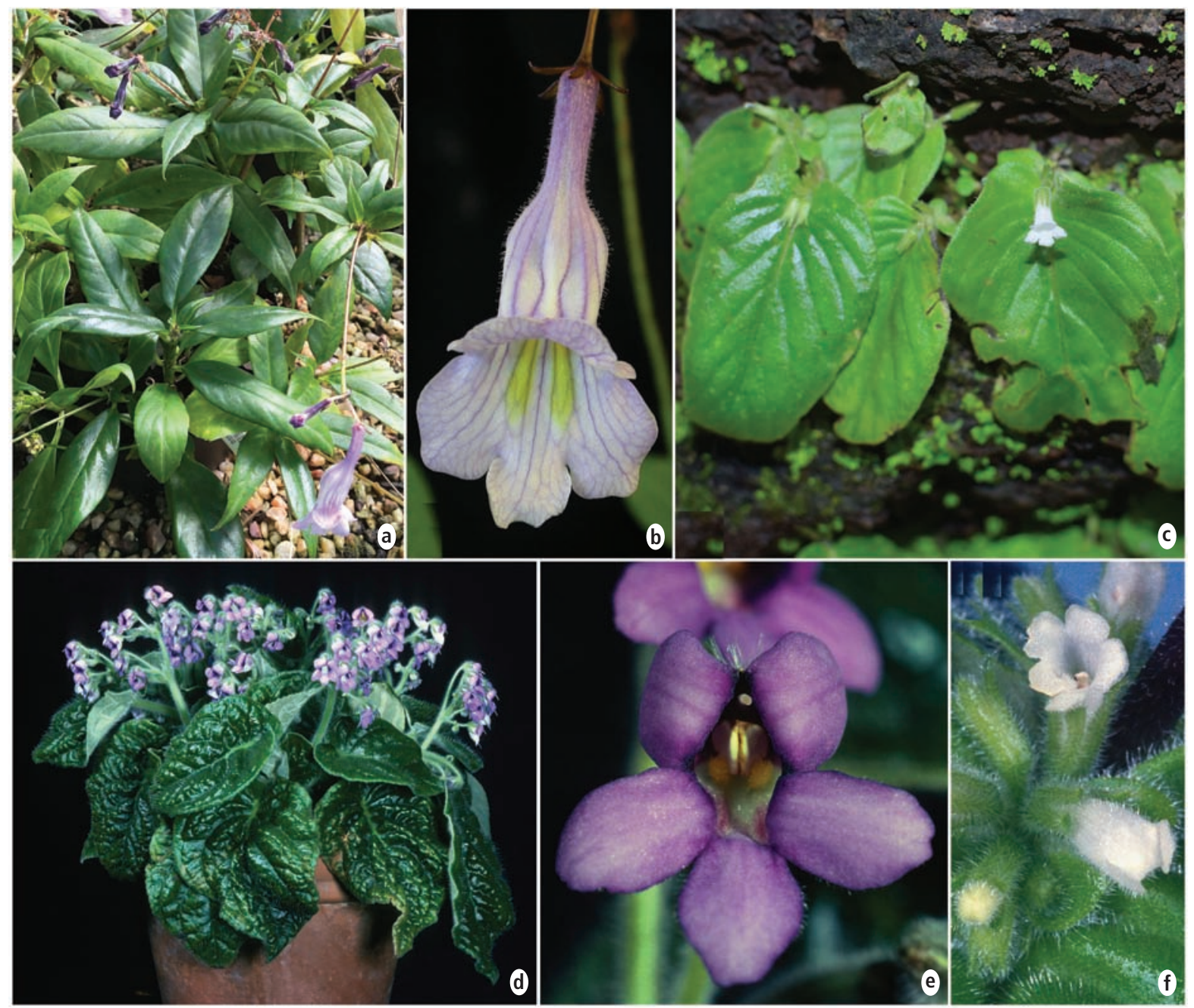

Fig. 5. Photographic images of Gesneriaceae occurring in India and adjacent areas. a, b. Lysionotus serratus D. Don, Thailand: a. Flower; b. Habit; c, d. Microchirita hamosa (C.B. Clarke) Yin Z. Wang: c. Habit; d. Flowers; e, f. Petrocosmea parryorum C.E.C. Fisch.: e. Habit; f. Flower (Images; a, b: Michael Möller, RBGE; d-f: RBGE archive; c: Karan Rana, University of Baroda. All with permission).

and often crested inflorescences with peduncles displaced onto the petiole (Weber, 1975). 28 spp. described, perhaps more; growing \pm exclusively growing on karst limestone rocks, either in forest or on exposed rocks in the open (sun-tolerant to some degree). From the Western Ghats and the foothills of the Himalayas of India, through continental Southeast Asia to Indonesia (Borneo, Sumatra and Java). The highest concentration of species is in Thailand. 2 spp. in India.

\section{Oreocharis Benth.}

Perennial rosette plants, indumentum variable, sometimes rufescent-lanuginose. Leaves spirally arranged, petiolate, of variable shape. Cymes pedunculate-scapose, flowers in corymbose or subumbellate arrangement, or lax, or reduced to a single flower; bracteoles small. Flowers 5-merous, bilabiate, rarely 4- or 5-merous and actinomorphic. Sepals nearly free to base, or fused halfway. Corolla colouration variable, blue, purple, red, orange, yellow and white, extraordinarily variable in size and shape, ranging from campanulate through funnel-shaped, infundibuliform to broad-tubular, tube straight or ventricose; limb with equal lobes or bilabiate; lobes rotundate or lanceolate or almost absent. Stamens 4 or 5 , of equal length or didynamous, or 2 (either the posterior or the anterior pair reduced), either included, equalling or protruding far out from the corolla; filaments inserted at corolla base or above; anthers free or connate. Nectary cylindrical. Ovary usually glabrous; stigma capitate or bilobed. Capsules bi- or four-valved, loculicidally (and septicidally) dehiscent.

Note: The genus has recently been enlarged by the inclusion of about 10 Chinese genera (Möller et 
al., 2011b, 2014), and is morphologically difficult to circumscribe based on floral characters but the species share a basal rosette with spiral leaf arrangement and capsules dehiscing predominantly on one side (Möller et al., 2011b) and $x=17$ chromosomes (Möller \& Pullan, 2015 onwards). All rosette-forming species of Briggsia, including the type (B. longifolia), were transferred to Oreocharis (Möller et al., 2011b, 2014; Chen et al., 2014), including one of the two species occurring in NE India, B. muscicola [now Oreocharis muscicola (Diels) Mich. Möller \& A. Weber; Middleton et al., 2013]. More than 109 spp.; N India, S China (107 spp.), Bhutan, Myanmar, N Thailand, Vietnam. 1 sp. [O. muscicola (Diels) Mich. Möller \& A. Weber, the former Briggsia muscicola (Diels) Craib] in India.

\section{Petrocosmea Oliv. (Fig. 5e \& f)}

Perennial herbs. Leaves few to many, in a basal rosette, petiolate or sessile (several species with both petiolate and sessile leaves), ovate to orbicular, apex acute, obtuse or rounded, base cuneate to cordate, rarely peltate. Cymes pedunculate, fewto several-flowered, lax, rarely subumbellate; bracteoles present. Calyx 3-partite; lobes equal, free or fused. Corolla white, or purple to blue shades, short-tubed, flat-faced; tube broad, shorter than the bilabiate limb; lobes rounded. Stamens 2; filaments short, inserted near corolla base; anthers basifixed, coherent at apices, thecae parallel, apically confluent or not, longicidally dehiscent. Nectary lacking. Ovary ovoid or conical; stigma capitate or globose. Capsules ovoid or oblong, dehiscing loculicidally.

Note: 43 spp.; NE India, S China (35 spp.), Myanmar, Thailand, S Vietnam. 1 sp. (P. parryorum C.E.C. Fisch.) in India.

\section{Biogeographic considerations for India}

It is remarkable that India harbours native Gesneriaceae members in 3 out of 4 subtribes of tribe Epithemateae and 6 out of 10 subtribes in tribe Trichosporeae, i.e., 9 out of 14 in subfamily Didymocarpoideae (Fig. 1). This high level of diversity underlines the biogeographic importance of India for the family Gesneriaceae.

A clear geographic divide is present among the Indian Gesneriaceae with 13 genera exclusively distributed in the North, and predominantly in the Northeast (Beccarinda, Boeica, Didymocarpus, Dorcoceras, Hemiboea, Leptoboea, Loxostigma, Lysionotus, Middletonia, Oreocharis, Petrocosmea,
Platystemma, and Tetraphyllum) (Fig. 6). These represent mostly westwards extensions of genera with main centre of distribution in the Himalayas (Nepal, Bhutan, Myanmar), China and Indochina.

On the Indian mainland one genus is exclusively restricted to the South, Jerdonia, with the narrow endemic, J. indica in the Western Ghats of Karnataka, Kerala and Tamil Nadu (Janeesha \& Nampy, 2014). It forms the basal most lineage in tribe Trichosporeae in phylogenetic analyses (Möller et al., 2009), and is perhaps a relic from the distant past of the tribe.

Aeschynanthus, Corallodiscus, Epithema, Henckelia, Microchirita, Rhynchoglossum and Rhynchotechum have members in the North and South of India. These genera cover five subtribes in both tribes, which indicates that the Old World Gesneriaceae were more widespread in the past across this country. Corallodiscus is especially interesting because of the wide distribution of the one species occurring in India, C. lanuginosus with a distribution range from near Beijing in China to the Western Ghats (Zhou et al., 2017).

The Andaman and Nicobar Islands harbour 8 species of Gesneriaceae in 5 genera, Aeschynanthus (3 spp.), Cyrtandra (2 spp.), Epithema (1 sp.), Rhynchotechum (1sp.), and Stauranthera (1 $1 \mathrm{sp}$.). These represent three subtribes of both Old World tribes Epithemateae and Trichosporeae. Cyrtandra occurs only on the Great Nicobar Island. It is interesting to note that three of these have either fleshy berries (Cyrtandra, Rhynchotechum), or seed appendages (Aeschynanthus) aiding bird or wind dispersal, respectively (Mendum et al., 2001; Weber, 2004; Kokubugata et al., 2011), which could explain their occurrence on the Andaman and Nicobar Islands. This group of island is situated between two major biodiversity hotspots, the Indian subcontinent and the Malaysian-Indonesian region (Malesia) and consequently contains floristic elements representative of the Indian, Myanmarese, Thai, and Malesian floras. For the Nicobar Islands, the flora resembles closer that of Malesia rather than India (Balakrishnan \& Ellis, 1996), which may explain the presence of Gesneriaceae genera on the islands that are essentially centred in Central and Southeast Asia.

\section{Conclusions and summary}

To date the genus count for Gesneriaceae in India is 23. Three genera are no longer found in India: Briggsia, Boea and Paraboea. Dorcoceras and Middletonia are new names for India. Cyrtandromoea 

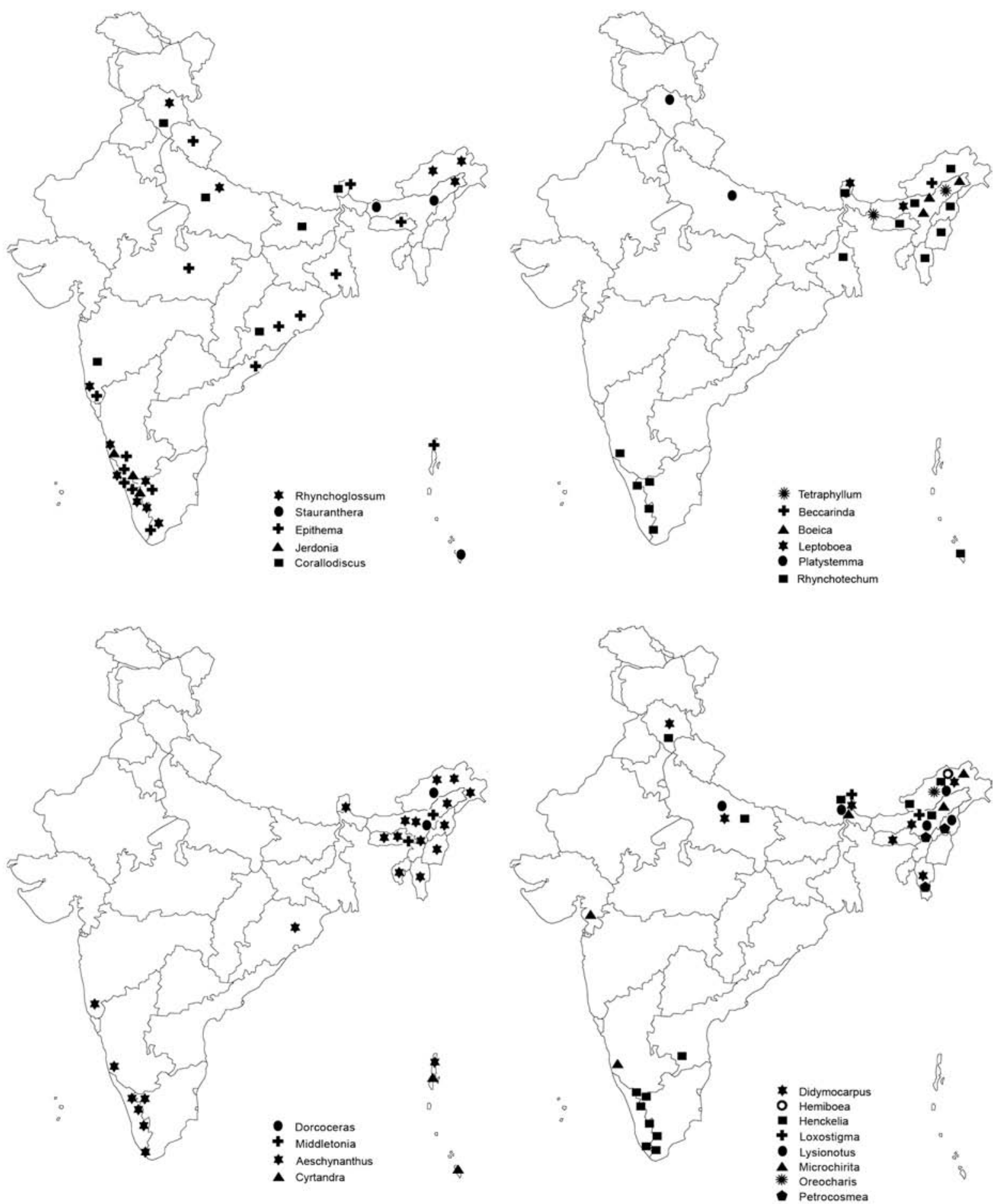

Fig. 6. Distribution maps of Gesneriaceae of India by genus. Data from field, herbarium and literature.

has been excluded from the family. The morphological definitions for a few genera have changed, widened (e.g. Henckelia and Loxostigma), narrowed for others by exclusion from larger genera and resurrection or establishment of new genera (e.g. Dorcoceras from Boea and Middletonia from Paraboea). For some genera like Henckelia more work is perhaps needed to come to a final taxonomic framework.

The Indian Gesneriaceae contain important lineages such as Jerdonia or Corallodiscus the former being remarkable for its many morphological features 
unusual in the family, the latter for its conserved morphology, retained across the wide biogeographic distribution range of the species in India.

Within India, a strong biogeographic break is apparent in the distribution of Gesneriaceae with the northern species having strong links to those countries neighbouring India, predominantly China. This spilt is particularly apparent in Henckelia and is manifest also in a morphological divide. With such an array of diverse aspects, the family Gesneriaceae proves an interesting plant family to study in India.

\section{Acknowledgements}

We are grateful to Drs Carmen Puglisi and David Middleton (Singapore Botanic Gardens) for critical comments on the manuscript. One of the authors (JAP) is thankful to University Grants Commission (UGC), India for financial support of her Ph.D. study. Funding from the Sibbald Trust (projects 2015\#10 to JAP, 2016\#11 to SN) of the Royal Botanic Garden, Edinburgh (RBGE) is gratefully acknowledged for enabling research visits of JAP and SN to RBGE. We would like to thank Dr. Alfred Joe, Mr. P.G. Arunkumar, and Mr. V.S. Hareesh, Department of Botany, University of Calicut, Mr. Karan Rana, University of Baroda, and Dr. Gopal Krishna, Central National Herbarium (CAL), Botanical Survey of India and Bhaskar Adhikari, RBGE for providing photographic images. The RBGE is supported by the Scottish Government's Rural and Environmental Science and Analytical Services Division.

\section{Literature Cited}

Anderson, B.M. \& D.J. Middleton 2013. A revision of Rhynchotechum Blume (Gesneriaceae). Edinburgh J. Bot. 70(1): 121-176.

Atkins, H.J., Bramley, G.L.C. \& J.R. Clark 2013. Current knowledge and future directions in the taxonomy of Cyrtandra (Gesneriaceae), with a new estimate of species number. Selbyana 31(2): 157-165.

Balakrishnan, N.P. \& J.L. Ellis 1996. Andaman and Nicobar Islands. In: Hajra, P.K., B.D. Sharma, M. Sanjappa \& A.R.K. Sastry (eds.), Flora of India, Introductory Volume. Part 1. Botanical Survey of India, Calcutta.

Bhattacharyya, U.C. \& A.K. Goel 2014. Systematic account of the genus Aeschynanthus Jack (Gesneriaceae) in India. Phytotaxonomy 14: $1-22$.
Bransgrove, K. \& D.J. Middleton 2015. A revision of Epithema (Gesneriaceae). Gard. Bull. Singapore 67(1): 159-229.

Brown, R. 1839. On Cyrtandreae. From Dr. Horsfield's "Plantae Javanicae Rariores." Pl. 24, pp. 1-2, pl. 25, pp. 105-122. Richard \& John E. Taylor, London.

Burtt, B.L. 1947. Didissandra and Corallodiscus. Gard. Chron. ser. 3, 122: 204, 212.

Burtt, B.L. 1962a. Studies in the Gesneriaceae of the Old World XXI. Rhynchotechum and Isanthera. Notes Roy. Bot. Gard. Edinburgh 24: 35-39.

Burtt, B.L. 1962b. Studies in the Gesneriaceae of the Old World XXIII. Rhynchoglossum and Klugia. Notes Roy. Bot. Gard. Edinburgh 24: 167-171.

Burtt, B.L. 1963. Studies in the Gesneriaceae of the Old World XXIV: tentative keys to the tribes and genera. Notes Roy. Bot. Gard. Edinburgh 24: 205-220.

Burtt, B. L. 1975. Studies in the Gesneriaceae of the Old World XL: The genus Loxostigma. Notes Roy. Bot. Gard. Edinburgh 34: 101-105.

Burtt, B.L. 1984. Studies in the Gesneriaceae of the Old World: XLVII. Revised generic concepts for Boea and its allies. Notes Roy. Bot. Gard. Edinburgh 41: 401-452.

Burtt, B.L. \& H. Wiehler 1995. Classification of the family Gesneriaceae. Gesneriana 1(1): 1-4.

Chen, W.H., Shui, Y.M. \& M. Möller 2014. Two new combinations in Oreocharis (Gesneriaceae) from China. Candollea 69(2): 179-182.

Clarke, C.B. 1884 [“1885”]. Gesneriaceae. In: Hooker, J.D. (ed.), The Flora of British India. Vol. 4. L. Reeve \& Co. Ltd., London. pp. 336-375.

Craib, W.G. 1919. Didissandra and allied genera in China and N. India. Notes Roy. Bot. Gard. Edinburgh 11: 255-268.

Diels, F.L.E. 1912. Plantae Chinenses Forrestianae, new and imperfectly known species. Notes Roy. Bot. Gard. Edinburgh 5: 224-226.

Evans, W.E. 1928. Briggsia kurzii (Clarke) W.E. Ev. comb. nov. Notes Roy. Bot. Gard. Edinburgh 16: 133-134.

Janeesha, A.P. \& S. Nampy 2014. Jerdonia (Gesneriaceae): A little-known, endemic Indian genus from southern Western Ghats. ENVIS Newslett. 19(2): 4-5.

Janeesha, A.P. \& S. Nampy 2015. Henckelia bracteata, a new species of Gesneriaceae from S Western Ghats, India, and lectotypification of 
Didymocarpus humboldtianus (H. humboldtiana). Willdenowia 45: 53-59.

Joe, A., Hareesh, V.S., Prashob, P. \& M. Sabu 2016. Didymocarpus moellerii (Gesneriaceae): a new species from northeastern India. Phytotaxa 266(1): 57-60.

Kamble, M.Y., Shendage, S.M. \& S.R. Yadav 2006. Corallodiscus Batalin (Gesneriaceae) - A new generic record for Peninsular India. Rheedea 16(1): 63-65.

Kokubugata, G., Hirayama, Y., Peng, C.I., Yokota, M. \& M. Möller 2011. Phytogeographic aspects of Lysionotus pauciflorus sensu lato (Gesneriaceae) in the China, Japan and Taiwan regions: phylogenetic and morphological relationships and taxonomic consequences. $\mathrm{Pl}$. Syst. Evol. 292(3): 177-188.

Kumar, E.S.S. 2013. Anew combination in Henckelia (Gesneriaceae). Polish Bot. J. 59(1): 149.

Li, J.M., Sun, W.J., Chang, Y. \& W.G. Yang 2016. Systematic position of Gyrocheilos and some odd species of Didymocarpus (Gesneriaceae) inferred from molecular data, with reference to pollen and other morphological characters. J. Syst. Evol. 54(2): 113-122.

Manudev, K.M., Weber, A. \& S. Nampy 2012. Henckelia pradeepiana, a new species of Gesneriaceae from the southern Western Ghats, India. Rheedea 22(2): 119-123.

Mendum, M., Lasnig, P., Weber, A. \& F. Christie 2001. Testa and seed appendage morphology in Aeschynanthus (Gesneriaceae): phytogeographical patterns and taxonomic implications. Bot. J. Linn. Soc. 135: 195-213.

Middleton, D.J. 2007. A revision of Aeschynanthus (Gesneriaceae) in Thailand. Edinburgh J. Bot. 64(3): 363-429.

Middleton, D.J. 2009. A revision of Aeschynanthus (Gesneriaceae) in Cambodia, Laos and Vietnam. Edinburgh J. Bot. 66(3): 391-446.

Middleton, D.J. \& M. Möller 2012. Tribounia, a new genus of Gesneriaceae from Thailand. Taxon 61(6): 1286-1295.

Middleton, D.J., Weber, A., Yao, T., Sontag, S. \& M. Möller 2013. The current status of the species hitherto assigned to Henckelia (Gesneriaceae). Edinburgh J. Bot. 70(3): 385-404.

Möller, M. \& J.L. Clark 2013. The state of molecular phylogenetic work in the family Gesneriaceae: a review. Selbyana 31(2): 95-125.
Möller, M. \& M. Pullan 2015 onwards. RBGE WebCyte2 - An updated Gesneriaceae cytology database. Accessed 7 February 2017.

Möller, M., Pfosser, M., Jang, C.G., Mayer, V., Clark, A., Hollingsworth, M.L., Barfuss, M.H.J., Wang, Y.Z., Kiehn, M. \& A. Weber 2009. A preliminary phylogeny of the "Didymocarpoid Gesneriaceae" based on three molecular data sets: incongruence with available tribal classifications. Amer. J. Bot. 96(5): 989-1010.

Möller, M., Forrest, A., Wei, Y.G. \& A. Weber 2011a. A molecular phylogenetic assessment of the advanced Asiatic and Malesian didymocarpoid Gesneriaceae with focus on non-monophyletic and monotypic genera. $\mathrm{Pl}$. Syst. Evol. 292(3-4): 223-248.

Möller, M., Middleton, D.J., Nishii, K., Wei, Y.G., Sontag, S. \& A. Weber 2011b. A new delineation for Oreocharis incorporating an additional ten genera of Chinese Gesneriaceae. Phytotaxa 23: 1-36.

Möller, M., Chen, W.H., Shui, Y.M., Atkins, H. \& D.J. Middleton 2014. A new genus of Gesneriaceae in China and the transfer of Briggsia species to other genera. Gard. Bull. Singapore 66(2): 195-205.

Möller, M., Wei, Y.G., Wen, F., Clark, J.L. \& A. Weber 2016. You win some you lose some: updated generic delineations and classification of Gesneriaceae - implications for the family in China. Guihaia 36(1): 44-60.

Puglisi, C., Yao, T.L., Milne, R., Möller, M. \& D.J. Middleton 2016. New generic recircumscription of the Loxocarpinae (Gesneriaceae), as inferred by phylogenetic and morphological data. Taxon 65(2): 277-292.

Rout, N.C., Dhal, N.K., Dash, P.K. \& A.K. Biswal 2008. Corallodiscus Batalin (Gesneriaceae): A new generic record for Eastern Ghats, Orissa. Curr. Sci. 95(1): 23-24.

Schäferhoff, B., Fleischmann, A., Fischer, E., Albach, D.C., Borsch, T., Heubl, G. \& K.F. Müller 2010. Towards resolving Lamiales relationships: insights from rapidly evolving chloroplast sequences. B. M. C. Evol. Biol. 10: 352.

Sinha, B.K. \& S. Datta 2016. Taxonomic account on the family Gesneriaceae in Northeast India. Nelumbo 58: 1-43.

Skog, L.E. \& J.K. Boggan 2007. World Checklist of Gesneriaceae. Dept. of Botany, Smithsonian 
Institution, Washington, D.C. http://botany. si.edu/Gesneriaceae/Checklist.

The International Plant Names Index 2012. Published on the Internet http://www.ipni. org [accessed 10 February 2017].

Wang, W.T., Pan, K.Y., Li, Z.Y., Weitzman, A.L. \& L.E. Skog 1998. Gesneriaceae. In: Wu, Z.Y. \& P.H. Raven (eds.), Flora of China. Vol. 18. Science Press, Beijing and Missouri Botanical Garden Press, St. Louis. pp. 244-401.

Wang, Y.Z., Mao, R.B., Liu, Y., Li, J.M., Dong, Y., Li, Z.Y. \& J.F. Smith 2011. Phylogenetic reconstruction of Chirita and allies (Gesneriaceae) with taxonomic treatments. J. Syst. Evol. 49: 50-64.

Weber, A. 1975. The cristate inflorescence of Chirita sect. Microchirita (Gesneriaceae). Notes Roy. Bot. Gard. Edinburgh 34: 221-230.

Weber, A. 1989. Family position and conjectural affinities of Charadrophila capensis Marloth. Bot. Jahrb. Syst. 111: 87-119.

Weber, A. 2004. Gesneriaceae. In: Kubitzki, K. \& J.W. Kadereit (eds.), The families and genera of vascular plants. Vol. 7. Flowering plants. Dicotyledons. Lamiales (except Acanthaceae, including Avicenniaceae). Springer, Berlin/ Heidelberg. pp. 63-158.
Weber, A. \& B.L. Burtt 1998. Remodelling of Didymocarpus and associated genera (Gesneriaceae). Beitr. Biol. Pflanzen 70: 293-363.

Weber, A., Middleton, D.J., Forrest, A., Kiew, R., Lim, C.L., Rafidah, A.R., Yao, T.L. \& M. Möller 2011a. Molecular systematics and remodelling of Chirita and associated genera (Gesneriaceae). Taxon 60(3): 767-790.

Weber, A., Wei, Y.G., Sontag, S. \& M. Möller 2011b. Inclusion of Metabriggsia into Hemiboea (Gesneriaceae). Phytotaxa 23: 37-48.

Weber, A., Clark, J.L. \& M. Möller 2013. A new formal classification of Gesneriaceae. Selbyana 31(2): 68-94.

Wight, R. 1850. Gesneraceae. In: Hunt, P.R. (ed.), Illustrations of Indian Botany. Vol. 2. Madras. pp. 180-182, pl. 159-159b.

Zhou, P., Li, J. \& M. Möller 2017. Secondary contact, hybridization and polyploidization add to the biodiversity in the Hengduan Mountains, exemplified by the widespread Corallodiscus lanuginosus (Gesneriaceae). Pl. Syst. Evol. 303(5): 587-602. DOI 10.1007/s00606-017-1392-0

Received: 2.11.2016

Revised and Accepted: 12.6.2017 